\title{
DIAKRONIKA
}

Vol. 18 No. 2 Th. 2018 p: 111-123

ISSN: 1411-1764 (Print) | 2620-9446 (Online)

http://diakronika.ppj.unp.ac.id

\section{Pengajaran IPS: Antara Gagasan Dan Pelaksanaan Di SMPN Kota Padang}

\author{
Etmi Hardi dan Wahidul Basri \\ etmihardi@yahoo.co.id, wahidulsejarahunp@gmail.com \\ Universitas Negeri Padang
}

\begin{abstract}
Integrated social studies learning has begun to be applied in various middle school (Sekolah Menengah Pertama) in Padang, especially since 2007. The principle of integration is integrating four fields of study, namely geography, economics, history and sociology into a certain theme. Integrated learning, firstly stated in the 2013 curriculum ideally, but in practice, it was different. Teachers at schools still cannot fully implement the Integrated Social Studies learning as appropriate, including SMP in Padang city. The purpose of this study is to see how Social studies which are in the Public Middle School in Padang. This research was conducted in several junior high schools in Padang. 8 of 43 public junior high schools in Padang to be the research subject, choose randomly, namely SMPN 1, SMPN 2, SMPN 6, SMPN 7, SMPN 8, SMPN 15, SMPN 16, dan SMPN 35. Data were collected through interviews with some social studies teachers, the Ministry of Education in Padang, and education observers in Padang. Research data was also collected through studies documentation and direct observation in class. The result shows that most social studies teachers at Padang in Junior High School not yet able to carry out Integrated Social Studies learning. There are still weaknesses in the selection of learning models which can support social studies learning, media and source selection improper learning.
\end{abstract}

Keywords : Integrated social, middle school, the principle of integration

\begin{abstract}
Abstrak
Pembelajaran IPS secara terpadu sudah mulai diterapkan di berbagai Sekolah Menengah Pertama (SMP) Negeri di Kota Padang, khususnya sejak tahun 2007 yang lalu. Prinsip keterpaduan disini ialah mengintegrasikan empat bidang studi (geografi, ekonomi, sejarah dan sosiologi) ke dalam proses pembelajaran. Gagasan yang dibangun dalam pembelajaran terpadu sebagaimana yang termaktub dalam Kurikulum 2013 (2013) demikian idealnya, akan tetapi dalam pelaksanaan ternyata tidaklah seperti itu. Para guru di sekolah-sekolah masih belum sepenuhnya dapat melaksanakan pembelajaran IPS secara terpadu sebagaimana mestinya, termasuk di SMPN di Kota Padang. Tujuan penelitian ini adalah untuk melihat bagaimana pelaksanaan pembelajaran IPS pada SMP Negeri di Kota Padang. Penelitian ini dilakukan pada beberapa SMPN di Kota Padang. Dari 43 SMPN yang ada di Kota Padang dipilih 8 SMPN sebagai subjek
\end{abstract}


penelitian secara acak, yaitu SMPN 1, SMPN 2, SMPN 6, SMPN 7, SMPN 8, SMPN 15, SMPN 16, dan SMPN 35. Data dikumpulkam melalui wawancara dengan sejumlah guru IPS, pejabat Dinas Pendidikan Kota Padang, dan pengamat pendidikan di Kota Padang. Di samping itu data penelitian juga dikumpulkan melalui studi dokumentasi dan observasi langsung ke dalam kelas. Hasil penelitian menunjukkan bahwa sebagian besar guru IPS di SMPN Kota Padang belum mampu melaksanakan pembelajaran IPS secara terpadu. Mereka masih cenderung mengajarkan IPS secara parsial per bidang studi. Di samping itu masih terdapat kelemahan kelemahan di dalam pemilihan model pembelajaran yang dapat menunjang pembelajaran IPS, pemilihan media dan sumber belajar yang tidak tepat, serta soal-soal penilaian hasil belajar masih berbasis disiplin ilmu.

Kata kunci: Pembelajaran IPS, SMP, Prinsip keterpaduan

(i) (2) This work is licensed under the Creative Commons Attribution-Share Alike 4.0 International License.

\section{Pendahuluan}

Sekalipun pengajaran IPS relatif baru dikenal di Indonesia, namun Social Studies (Studi Ilmu IImu Sosial) sebagai cikal bakal IPS di Indonesia telah dipopulerkan di Amerika Serikat setelah Perang Dunia II. Pada tahun 1970-an model Social Studies tersebut diadopsi oleh Indonesia dengan nama IPS (IImu Pengetahuan Sosial). Pengajaran IPS mulai dimasukkan ke dalam kurikulum pendidikan. Implikasinya mulai dibuka jurusan atau program studi IPS di beberapa perguruan tinggi di Indonesia, termasuk IKIP Padang (sekarang UNP).

Sejak kemunculannya, IPS telah mengalami perkembangan, sekaligus berbagai macam persoalan, yang dalam banyak hal memberi citra negatif terhadap bidang studi itu, sehingga untuk beberapa lama IPS tenggelam dalam khasanah pengajaran. Akan tetapi sejak diterapkannya Kurikulum Berbasis Kompetensi (KBK), Kurikulum Tingkat Satuan Pendidikan (KTSP), hingga Kurikulum Tahun 2013 (K-13) pengajaran IPS menjadi penting lagi, karena adanya kebijakan untuk menggabung beberapa bidang studi ke dalam IPS, meliputi sejarah, ekonomi, geografi dan sosilogi.

Model pembelajaran terpadu pada hakekatnya merupakan suatu pendekatan pembelajaran yang memungkinkan peserta didik, baik secara individual, maupun kelompok aktif mencari, menggali dan menemukan konsep dan prinsip keilmuan secara holistik, bermakna, dan otentik (Nasional, 2006). Dengan cara seperti itu siswa dapat memperoleh pengalaman 
langsung, sehingga dapat menambah kekuatan untuk menerima, menyimpan dan memproduksi kesan-kesan tentang apa yang dipelajarinya. Dalam pembelajaran IPS prinsip keterpaduan itu menjadi amat penting sebab mata pelajaran IPS bertujuan untuk mengembangkan potensi peserta didik agar peka terhadap masalah sosial yang terjadi dilingkungan sekitarnya, serta memiliki sikap mental positif terhadap perbaikan segala ketimpangan yang terjadi. Di samping itu peserta didik juga diharapkan terampil mengatasi setiap persoalan yang terjadi di lingkungan masyarakatnya (Alma, 2010). Dengan demikian pembelajaran IPS tidak hanya ditujukan untuk mengasah kemampuan kognitif anak, tetapi juga kemampuan afektif, guna membangun kehidupan masa depan yang lebih baik.

Melalui pembelajaran IPS secara terpadu peserta didik dapat memperoleh pengalaman langsung, sehingga dapat menambah kekuatan untuk menerima, menyimpan, dan memproduksi kesan-kesan tentang hal-hal yang dipelajarinya. Dengan demikian, peserta didik terlatih untuk dapat menemukan sendiri berbagai konsep yang dipelajari secara holistik, bermakna, otentik dan aktif. Cara pengemasan pengalaman belajar yang dirancang guru sangat berpengaruh terhadap kebermaknaan pengalaman bagi para peserta didik. Pengalaman belajar hendaknya menunjukkan kaitan unsurunsur konseptual menjadikan proses pembelajaran lebih efektif. Kaitan konseptual yang dipelajari dengan sisi bidang kajian yang relevan akan membentuk skema (konsep) sehingga peserta didik memperoleh keutuhan dan kebulatan pengetahuan.

Berdasarkan pengamatan dan pengalaman tim peneliti saat melaksanakan pendampingan teknis pembelajaran IPS untuk SMP di kota Padang dan Solok ternyata pembelajaran IPS sebagian besar masih dilaksanakan secara terpisah. Pencapaian Standar Kompetensi dan Kompetensi Dasar mata pelajaran IPS masih dilakukan berdasarkan bidang kajian masingmasing (sosiologi, sejarah, geografi, ekonomi) tanpa ada keterpaduan di dalamnya. Hal ini tentu saja menghambat pencapaian tujuan IPS yang dirumuskan atas dasar realitas dan fenomena sosial yang menunjukkan suatu pendekatan interdisipliner dari aspek dan cabang-cabang ilmu sosial (sosiologi, sejarah, geografi, ekonomi). Hal tersebut disebabkan antara lain: (1) kurikulum IPS tidak menggambarkan satu kesatuan yang terintegrasi, melainkan masih terpisah-pisah antar bidang ilmu-ilmu sosial; (2) latar belakang guru yang mengajar juga berasal dari beragam disiplin ilmu yang terpisah dan berdiri sendiri, meliputi geografi, sejarah, ekonomi, dan sosiologi sehingga sangat sulit bagi mereka melakukan pembelajaran yang memadukan antardisiplin ilmu tersebut; (3) terdapat kesulitan dalam pembagian tugas dan waktu pada masing-masing guru "mata pelajaran" untuk pembelajaran IPS secara terpadu; 
dan (4) meskipun pembelajaran terpadu bukan merupakan hal yang baru namun para guru di sekolah tidak terbiasa melaksanakannya sehingga "dianggap" hal yang baru.

Masalah lain yang ditemukan dalam pembelajaran IPS di sekolah adalah lemahnya proses pembelajaran. Proses pembelajaran di sekolah kurang mendorong anak untuk mengembangkan kemampun berpikir kritis. Berfikir kritis sangat perlu dalam proses pembelajarah (Karima, 2016). Pembelajaran IPS masih diarahkan agar anak mampu mengingat fakta dan informasi sebanyak mungkin sehingga anak harus menghafal, tanpa memahami apa yang dihafalnya. Dengan kata lain, pembelajaran IPS saat ini cenderung berorientasi pada hasil akhir/produk berupa pengetahuan baik itu pengetahuan prosedural, faktual maupun konseptual dan mengabaikan proses yang dapat menumbuhkan sikap dan mengembangkan keterampilan.

Fenomena di atas menggambarkan bahwa guru IPS masih mengalami berbagai kesulitan dalam mengimplementasikan mata pelajaran IPS secara terpadu. Menariknya hal seperti itu demikian juga terjadi di Kota Padang. Padahal dari segi kualifikasi, mayoritas guru guru SMP yang mengajar IPS di berbagai sekolah sudah bersertifikasi, atau memperoleh sertifikat pendidik di bidang IPS. Sertifikat pendidik itu seharusnya sudah menggambarkan profesionalitas mereka sebagai guru IPS, akan tetapi kenyataannya tidaklah demikian. Fenomena ini tentunya menarik untuk diteliti lebih lanjut, bagaimana wajah pembelajaran IPS secara terpadu yang dijalankan di SMP Negeri Kota Padang, dan persoalan apa yang masih dihadapi guru dalam proses pembelajaran IPS sehingga antara gagasan dan pelaksaannya masih belum berbanding lurus.

Sesuai dengan namanya IPS secara terpadu, maka model pembelajaran IPS harus dilakukan secara terpadu. Terpadu dalam dua hal, pertama materinya, dan kedua pendekatannya. Materi IPS diramu dari ilmu-ilmu sosial, yaitu: sejarah, ekonomi, geografi, dan sosiologi. (Maryanto, 1994) menyebutnya dengan pengajaran lintas batas bidang studi. Proses pembelajaran IPS di sekolah harus dilakukan secara terpadu, sehingga seorang guru IPS bukanlah guru sejarah, bukan guru ekonomi, bukan guru geografi, atau juga bukan guru sosiologi. Oleh sebab itu pembelajaran IPS harus dilakukan dengan “Model Tematis", yakni mengembangkan dari tema-tema yang ada pada keempat bidang studi itu (sejarah, ekonomi, geografi, dan sosiologi).

Pembelajaran terpadu pada hakekatnya merupakan sistem pendidikan yang memungkinkan peserta didik, baik secara individu, maupun kelompok 
aktif dalam mencari, menggali, dan menemukan konsep serta prinsip secara holistik dan otentik (Nasional, 2006). Pembelajaran terpadu dalam IPS dapat dikembangkan dalam tiga model, yaitu: model integrasi berdasarkan topik, model integrasi berdasarkan potensi utama, dan model integrasi berdasarkan permasalahan (Trianto, 2012).

Dalam model integrasi berdasarkan topik, sebuah tema/topik yang berada dalam satu sisiplin ilmu sosial, didekati dari beberapa disiplin ilmu sosial lainnya. Sedangkan dalam model integrasi berdasarkan potensi utama, tema/topik dikembangkan dari potensi utama yang berada di sebuah wilayah, misalnya potensi budaya atau pariwisata. Model integrasi berdasarkan permasalahan mencoba mengambangkan tema/topik berdasarkan permasalahan-permasalahan sosial yang ada di tengah masyarakat.

Pembelajaran terpadu memiliki beberapa perbedaan mendasar jika dibandingkan dengan pendekatan satu bidang studi yang otonom. Pembelajaran terpadu memiliki empat ciri utama, yakni: holistik, bermakna, otentik, dan aktif. Holistik maksudnya suatu gejala atau fenomena diamati dan dikaji dari beberapa bidang kajian. Bermakna dilihat dari segi peserta didik, dimana peserta didik mampu memecahkan berbagai persoalan dalam masyarakat dengan menggunakan berbagai konsep dari disiplin ilmu. Otentik dalam arti informasi yang didapat peserta didik lebih asli karena diperoleh melalui analisis dan pemahaman dengan menggunakan berbagai disiplin ilmu. Selanjutnya aktif menyangkut keterlibatan peserta didik di dalam mengolah informasi. Dalam pembelajaran peserta didik dituntut untuk terlibat secara aktif baik fisik, mental, intelektual, maupun emosional (Trianto, 2012).

Salah satu komponen yang amat menentukan keberhasilan pembelajaran IPS secara terpadu adalah guru. Oleh karena IPS merupakan gabungan dari beberapa disiplin ilmu sosial secara terintegrasi, maka guru harus memiliki kemampuan yang lebih untuk mengajarkannya, di sampingia juga harus memiliki wawasan yang luas. Pembelajaran IPS dapat dilaksanakan oleh seorang guru (tunggal) atau dengan carateam teaching. Model guru tunggal menggunakan satu orang guru dimana ia memiliki kebebasan untuk merancang sendiri pembelajarannya disertai dengan rasa tanggung jawab yang tinggi. Sementara dalam model pembelajaran team teaching, pembelajaran IPS dilakukan dengan melibatkan beberapa orang guru. Setiap topik pembelajaran disampaikan oleh guru yang berbeda sesuai dengan bidang keahliannya (Kependidikan, JENDERAL, KEPENDIDIKAN, \& NASIONAL, 2008).

Menyangkut Standar Isi, IPS ditetapkan berdasarkan Peraturan Menteri Pendidikan Nasional Nomor 22 Tahun 2006. Dalam Permen 22 tersebut 
ditegaskan bahwa IPS merupakan salah satu mata pelajaran yang diberikan mulai dari tingkat SD/MI/SDLB sampai ke tingkat SMP/MTs/SMPLB. Pada tingkat SD/MI/SDLB materi pelajaran IPS meliputi: sejarah, geografi, dan koperasi. Sementara pada jenjang SMP/MTs/SMPLB bahan kajian IPS meliputi empat bidang studi, yaitu: sosiologi, sejarah, geografi dan ekonomi (Mulyasa, 2007)

Menurut (Nasional, 2006) model pembelajaran terpadu merupakan salah satu model implementasi kurikulum yang dianjurkan untuk diaplikasikan pada semua jenjang pendidikan, mulai dari tingkat Sekolah Dasar (SD/MI) sampai dengan Sekolah Menengah Atas (SMA/MA). Model pembelajaran terpadu pada hakikatnya merupakan suatu pendekatan pembelajaran yang memungkinkan peserta didik baik secara individual maupun kelompok aktif mencari, menggali, dan menemukan konsep serta prinsip secara holistik dan otentik. Dalam Kurikulum 2013, Kompetensi Inti (KI) dan Kompetensi Dasar (KD) Ilmu Pengetahuan Sosial (IPS) di tingkat Sekolah Menengah Pertama (SMP), meliputi bahan kajian: sosiologi, sejarah, geografi, ekonomi. Bahan kajian tersebut menjadi mata pelajaran Ilmu Pengetahuan Sosial (IPS).

Pada Permendikbud Nomor 103 tahun 2014 tentang Standar Proses Pembelajaran pada Pendidikan Dasar dan Menengah dijelaskan bahwa proses pembelajaran harus dilaksanakan dengan menggunakan pendekatan saintifik yang terdiri atas lima pengalaman belajar pokok. Lima pengalaman belajar tersebutyaitu: mengamati, menanya, mengumpulkan informasi, mengasosiasi dan mengomunikasikan. Pada pembelajaran IPS pendekatan saintifik dapat diterapkan melalui keterampilan proses. Keterampilan proses sosial merupakan seperangkat keterampilan yangdigunakan para ilmuan dalam melakukan penyelidikan ilmiah.

\section{Metode}

Penelitian ini termasuk ke dalam penelitian kualitatif dalam bentuk studi deskriptif. Metode kualitatif digunakan untuk mengamati masalah penelitian yang belum terlalu jelas, masih samar-samar, atau bahkan masih gelap. Sementara studi diskriptif berusaha untuk memberikan gambaran yang jelas dan akurat tentang sebuah fenomena yang diamati. Penelitian ini dilakukan di Sekolah Menengah PertamaNegeri (SMPN) di Kota Padang. Dari 43 SMPN yang adadipilih 8 sekolah sebagai objek penelitian secara acak. Pemilihan sekolah didasarkan pada dua pertimbangan. Pertama berdasarkan letak sekolah dari pusat kota, di mana ada sekolah yang berada di pusat kota dan ada sekolah yang berada jauh dari pusat kota. Kedua dari sisi persepsi 
masyarakat, di mana ada sekolah yang dianggap favorit dan ada yang tidak favorit. Perbedaan ini menyebabkan input siswa dan kondisi sekolah dari dua kategori itu juga berbeda. Berdasarkan dua pertimbangan itu maka terpilih delapan SMPN sebagai objek penelitian, yaitu SMPN 1, SMPN 2, SMPN 6, SMPN 7, SMPN 8, SMPN 15, SMPN 16, dan SMPN 35 Padang.

Data penelitian dikumpulkan melalui studi dokumentasi, observasi, dan wawancara lapangan. Pencatatan dokumen dilakukan diberbagai tempat, baik yang berada di sekolah, maupun di kantor Dinas pendidikan Kota Padang. Di samping itu juga digunakan dokumen pribadi milik guru IPS, seperti silabus dan RPP. Dalam pada itu juga dilakukan observasi langsung ke dalam kelas untuk mendapatkan data yang valid sesuai dengan tujuan penelitian. Selama observasi juga diikuti dengan wawancara secara simultan dan mendalam dari banyak kalangan, seperti guru IPS, kepala sekolah, dan pejabat pengambil keputusan (Dinas pendidikan Kota Padang). Semua data yang diperoleh kemudian dianalisis menggunakan model analisis interaktif dari Miles dan Huberman yang terdiri dari empat komponen yakni: pengumulan data, reduksi data, display data dan verifikasi data sebagai dasar untuk pengambilan keputusan.

\section{Pembahasan}

Sebagian besar guru-guru IPS yang mengajar di SMP Negeri Kota Padang adalah tamatan LPTK (Lembaga Pendidikan Tenaga Kependidikan) yang berada di Sumatera Barat, baik negeri maupun swasta, diantaranya Universitas Negeri Padang (dulu bernama IKIP Padang), STKIP PGRI Sumatera Barat, STKIP Dharma Bakti Lubuk Alung, dan FKIP Muhammadiah Sumatera Barat. Di samping itu beberapa orang guru diantarnya berasal dari lulusan non LPTK, namun sudah memperoleh ijazah Akta Mengajar (Akta IV) sehingga memiliki kewenangan untuk mengajar (wawancara dengan sejumlah guru IPS di SMP Negeri Kota Padang)

Dilihat dari aspek profesionalitas, mayoritas guru-guru IPS di SMPN Negeri Kota Padang sudah mendapatkan sertifikat pendidik, sehingga kemampuan mereka dalam pembelajaran IPS tidak diragukan lagi. Sertifikat pendidik yang mereka peroleh sebagian besar dilakukan melalui jalur portofolio dan sebagian lagi melalui jalur PLPG (Program Latihan Profesi Guru) yang diselenggarakan oleh Universitas Negeri Padang sejak tahun 2006 yang lalu (IPS, 2006).Jika dilihat dari latar belakang pendidikan, khususnya Program Studi S-1 yang ditempuh oleh guru-guru IPS di SMPNKota Padang ternyata amat beragam. Rata-rata guru IPS berasal dari satu Program Studi tertentu, seperti sejarah, geografi, dan ekonomi. Tidak satupun di antara mereka yang berlatar belakang Pendidikan Sosiologi. Di samping itu, 
menariknya lagi diantara guru-guru IPS itu ada yang berasal dari rumpun bidang ilmu di luar Ilmu-llmu Sosial, sebagai basis utama IPS, seperti dari keterampilan.Secara khusus di delapan SMP Negeri Kota Padang yang menjadi sasaran penelitian ini, latar belakang pendidikan guru IPS seperti terlihat pada tabel berikut ini.

\begin{tabular}{|c|c|c|c|}
\hline No & Nama Sekolah & Nama Guru & Latar Pendidikan \\
\hline \multirow[t]{3}{*}{1.} & SMP Negeri 1 Padang & Endang Iriani, S.Pd, M.M & Geografi \\
\hline & & Dra.Yessemina Yarmia & Geografi \\
\hline & & Eva Yulianti, S.Pd & Sejarah \\
\hline \multirow[t]{8}{*}{2.} & SMP Negeri 2 Padang & Elvi Nofrianti, S.Pd & Sejarah \\
\hline & & Erni Pradida, S.Pd & Geografi \\
\hline & & Maidarlis, S.Pd & Sejarah \\
\hline & & Yetti Helmizar, S.Pd & Ekonomi \\
\hline & & Elly Darti, S.Pd & Ekonomi \\
\hline & & Dra. Sivia Ratna Dewi & Ekonomi \\
\hline & & Nani Irmaningsih, S.Pd & Geografi \\
\hline & & Gusmawati, S.Pd & Geografi \\
\hline \multirow[t]{5}{*}{3.} & SMP Negeri 7 Padang & Syafitri Janir, S.Pd & Sejarah \\
\hline & & Dra. Dahlia Erni & Geografi \\
\hline & & Anamurni, S.Pd & Ekonomi \\
\hline & & Mardiati, S.Pd & Geografi \\
\hline & & Syafrizal Syair, M.Pd & Sejarah \\
\hline \multirow[t]{6}{*}{4.} & SMP Negeri 8 Padang & M.A.Riadi, M.Pd & Geografi \\
\hline & & Asmawati, S.Pd & Ekonomi \\
\hline & & Yuselmida, S.Pd & Ekonomi \\
\hline & & Dra. Helmaini & Sejarah \\
\hline & & Drs.Amridas & Geografi \\
\hline & & Watni, S.Pd & Sejarah \\
\hline \multirow[t]{5}{*}{5.} & SMP Negeri 6 Padang & Dra.Ti. Faizah Tahirah & Sejarah \\
\hline & & Suhaimi, S.Pd, E.Kop & Ekonomi \\
\hline & & Fatmiartati, S.Pd & Sejarah \\
\hline & & Hastuti, S.Pd & Sejarah \\
\hline & & Sherly Andilia & Geografi \\
\hline \multirow[t]{5}{*}{6.} & SMP Negeri 15 Padang & Usmanelty, S.Pd & Ekonomi \\
\hline & & Andesta & Geografi \\
\hline & & Yeni, SE & Ekonomi \\
\hline & & Wartini, S.Pd & Sejarah \\
\hline & & Erlina, S.Pd & Geografi \\
\hline \multirow[t]{4}{*}{7.} & SMP Negeri 16 Padang & Riza Padmi, S.Pd & Geografi \\
\hline & & Fitriawati, M.Pd & Ekonomi \\
\hline & & Dra. Rosmani & Geografi \\
\hline & & Umi Salmah, M.Pd & Ekonomi \\
\hline
\end{tabular}


8. SMP Negeri 35 Padang

Nila Patrisia, S.Pd

Asnimar, M.Pd

Geografi

Efnizar, S.Pd

Geografi

Tabel 1. Data Latar Belakang Pendidikan Guru IPS dari Delapan SMP Negeri di Kota Padang Sumber : Data Diolah Dari Data Based Delapan SMP Negeri di Kota Padang

Sebagaimana tuntutan Kurikulum Tahun 2013 (K-13), pembelajaran IPS di Sekolah Menengah Pertama adalah bersifat terpadu. Prinsip keterpaduan disini terutama adalah dari segi materi pembelajaran yang diramu dari berbagai rumpun ilmu sosial, yang dalam hal ini meliputi empat bidang studi, yaitu: geografi, sejarah, ekonomi, dan sosiologi. Kemampuan guru dalam meramu keempat bidang studi itu secara terpadu menjadi substansi penting dalam pembelajaran IPS. Disini sangat diharapkan profesionalitas guru IPS untuk dapat mengembangkan pembelajaran mulai dari tahap perencanaan pembelajaran, seperti menyiapkan Rencana Pelaksanaan Pembelajaran, Pelaksanaan Pembelajaran serta melakukan evaluasi.

Di Kota Padang implementasi K-13 di SMP dilakukan secara bertahap. Pada awal pelaksanaan hanya beberapa sekolah yang ditunjuk sebagai Pilot Project pelaksanaan K-13, diantaranya SMPN 1 Padang dan SMPN 8 Padang. Pada tahun-tahun pertama pelaksanannya, tidak semua tingkat kelas di kedua sekolah itu dilaksanakanpembelajaran IPS berdasarkan K-13, melainkan hanya pada kelas VII saja. Selanjutnya pada tahun kedua implementasi K-13 diperluas ke beberapa sekolah lainnya di Kota Padang. Di samping itu, pelaksanaanya dilakukan pada dua tingkat sekolah, yaitu Kelas VII dan VII (Prekar, 2018).

Mulai tahun 2018 Dinas Pendidikan Kota Padang mengeluarkan kebijakan bahwa seluruh SMP yang ada di Kota Padang, baik negeri, maupun swasta diwajibkan menjalankan K-13, termasuk bidang studi IPS (Data Dinas Pendidikan Kota Padang, Tahun 2018). Dengan keluarnya kebijakan ini maka pembelajaran IPS di seluruh SMPN yang ada di Kota Padang harus mampu mengimplementasikan kurikulum tersebut secara baik di lapangan, terutama dalam proses pembelajaran.

Hasil observasi tim peneliti di lapangan menunjukkan bahwa di delapan SMPN yang menjadi sasaran penelitian, SMPN tersebut telah menjalankan K-13 pada semua bidang studi (mata pelajaran) yang diajarkan, termasuk IPS. Sekalipun demikian di beberapa sekolah pelaksanaan K-13 baru terselenggara pada kelas VII dan kelas VIII, sementara kelas IX tetap 
menggunakan Kurikulum Tingkat Satuan Pendidikan (KTSP). Sekolah-sekolah tersebut adalah SMPN 6, SMPN 15, SMPN 16, dan SMPN 35. Sedangkan SMPN lainnya sudah menjalankan K-13 secara menyeluruh mulai kelas VII sampai kelas IX.

Hasil pengamatan lapangan dan wawancara dengan para guru IPS memperlihatkan bahwa pembelajaran IPS dilakukan dengan model guru tunggal, tidak team teaching. Dalam model guru tunggal, satu orang guru bertanggung jawab penuh untuk mengajarkan IPS pada satu kelas secara tuntas dalam satu semester. Dengan demikian masing-masing guru punya otonomi untuk mengembangkan pembelajaran IPS di dalam kelas dengan tetap mengacu pada rambu-rambu kurikulum. Berbeda halnya dengan team teaching, di mana dalam model ini para guru IPS dapat saling bekerjasama mengemas pembelajaran IPS, sehingga dalam satu semester mereka bisa masuk kelas secara bergantian.

Kurikulum Tahun 2013 memang lebih mendorong pembelajaran IPS dipegang oleh satu orang guru pada satu kelas tertentu. Namun K-13 juga memberi kesempatan pada guru untuk melaksanakan pembelajaran secara bersama (team teaching). Yang terpenting adalah tujuan pembelajaran seperti yang dituntut oleh kurikulum dapat terlaksana secara baik sehingga dapat mencapai tujuan yang diinginkan. Sebagaimana yang diminta dalam Kurikulum Tahun 2013 pembelajaran IPS adalah bersifat terpadu dengan model tematik. Satu tema tertentu harus didekati dengan banyak disiplin ilmu sosial sehingga bersifat integratif. Sebagai contoh tema yang bersifat geografis seperti Kerjasama ASEAN bisa ditelaah dari berbagai materi ilmu sosial lainnya, seperti sejarah, ekonomi, dan sosiologi. Begitu juga tema sejarah yang berkaitan dengan Kehidupan Masyarakat Indonesia Zaman Pra Aksara, bisa dijelaskan dari berbagai sudut ilmu sosial lainnya, seperti geografi, ekonomi, dan sosiologi.

Akan tetapi hasil penelitian lapangan menunjukkan bahwa pelaksanaan pembelajaran IPS di SMPN di Kota Padang kebanyakan masih bersifat parsial dan fragmentaris. Sebagian besar guru mengajarkan IPS secara terpisah sesuai dengan Kompetensi Dasar (KD) yang ada dalam kurikulum. Ketika KD dekat dengan sejarah maka guru hanya mengajarkam materi sejarah saja, tanpa dipadukan dengan materi-materi IPS lainnya. Demikian juga KD yang bersifat ekonomi cenderung diajarkan ekonomi saja. Akibatnya prinsip keterpaduan dalam IPS tersebut tidak berjalan sebagaimana mestinya. Gejala seperti ini hampir didapati di berbagai sekolah yang menjadi sasaran penelitian. Sekalipun demikian beberapa orang guru di SMP tetap konsisten menjalankan 
pembelajaran IPS seperti yang diminta dalam K-13, dimana prinsip keterpaduan tetap diusahakan untuk dicapai secara maksimal. Beberapa orang guru yang konsisten mengajarkan IPS secara terpadu itu ditemukan di beberapa sekolah, seperti SMPN 1 Padang, SMPN 7 Padang, dan SMPN 8 Padang.

Hasil wawancara dan observasi yang dilakukan terhadap Yessemina Yarmia, guru IPS SMPN 1 Padang, Syafrizal Syair guru IPS SMPN 7 Padang, dan Watni guru IPS 8 Padang menemukan bahwa mereka telah dapat melaksanakan pembelajaran IPS secara baik, terutama dari segi materi pembelajaran dan pendekatan pembelajaran. Sekalipun demikian pada aspekaspek tertentu mereka masih menemukan kesulitan dalam pembelajaran IPS yang terpadu.

Yessemina Yarmina guru IPS SMPN 1 Padang menjelaskan:

"Sekalipun Kompetensi Dasar (KD) yang terdapat di kelas VII dan VIII sebagian bersifat terpisah, misal ekonomi atau geografi saja, tetapi pada hakekatnya guru tetap dapat memadukannya. Beberapa materi bidang studi IPS dapat dipadukan pada KD-KD yang ada pada kurikulum. Ini semua tergantung pada kemauan dan motivasi guru" (Yarmina, 2018)

Watni, salah seorang guru IPS di SMPN 8 Padang juga memiliki pandangan yang hampir sama bahwa pembelajaran IPS secara terpadu dapat dilaksanakan oleh guru. Watni menegaskan:

"Sekalipun KD dalam K-13 ada yang bersifat terpisah namun guru dapat menterjemahkan dan mengembangkannya menjadi pembelajaran terpadu. Satu materi bidang studi dapat dipadukan dengan materi bidang studi lainnya (prinsip keterpaduan), misal materi ekonomi dikaitkan dengan sejarah, ataupun geografi” (Watni, 2018).

Selanjutnya Syafrizal Syair, guru IPS di SPMN 7 Padang, menjabat sebagai koordinator MGMP IPS Kota Padang menegaskan:

"Memang dalam kurikulum keterpaduan IPS hanya nampak di Standar Kompetensi (SK) dan di beberapa KD nampak terpisah. Namun guru punya kebebasan untuk mengembangkannya dalam pembelajaran. Guru boleh mengembangkan KD secara terpadu, satu tema atau topik pembelajaran bisa didekati dengan beberapa bidang studi IPS. Misalnya dalam KD Perang Kemerdekaan, bukan berarti materi pembelajaran tentang sejarah saja, tetapi harus juga dibicarakan hal-hal yang berkaitan dengan geografi, ekonomi dan sosiologi, Sebab perang bukan 
hanya menyangkut peristiwa saja, ada juga aspek geografis, ekonomi dan sosiologinya" (Syair, 2018).

Gambaran yang diperoleh dari beberapa orang guru IPS di beberapa sekolah menunjukkan bahwa pelaksanaan pembelajaran IPS sebenarnya dapat dilaksanakan sesuai dengan tuntutan kurikulum. Akan tetapi hal itu amat bergantung kepada kesiapan, kemauan dan keinginan guru di lapangan. Sebagai tenaga profesional guru IPS di Kota Padang sudah dilengkapi dengan pemahaman dan wawasan yang baik tentang pembelajaran IPS secara terpadu. Berbagai pelatihan, lokakarya dan bintek menyangkut pembelajaran IPS sudah diberikan oleh instansi terkait, seperti Dinas Pendidikan Kota Padang untuk meningkatkan pemahaman dan wawasan para guru IPS. Namun hal yang amat merisaukan hanya sebagian kecil guru IPS yang sudah menerapkan pembelajaran IPS secara terpadu di sekolah-sekolah.

\section{Kesimpulan}

Secara umum pembelajaran IPS berdasarkan K-13 belum berjalan sebagaimana mestinya. Fenomena ini terlihat di banyak SMPN yang ada di Kota Padang, khususnya SMPN yang berada di pinggir kota. Guru-guru masih cenderung mengjarkan IPS secara terpisah berdasarkan bidang studi tertentu. Hal ini terlihat dari pengorganisasian dan penyampaian materi pembelajaran di dalam kelas. Hanya beberapa orang guru di sekolah favorit yang berada di pusat kota yang sudah menjalankan pembelajaran IPS sebagaimana mestinya.

\section{Daftar Rujukan}

Alma, B. (2010). Pembelajaran Studi Sosial. Bandung: Alfabeta.

IPS, G. (2006). wawancara. padang.

Karima, E. M. (2016). No Title. Universitas Pendidikan Indonesia.

Kependidikan, D. T., JENDERAL, D., KEPENDIDIKAN, P. M. P. D. A. N. T., \& NASIONAL, D. P. (2008). Strategi Pembelajaran dan Pemilihannya. Jakarta: Direktorat Jenderal Peningkatan Mutu Pendidikan Dan Tenaga Kependidikan Departemen Pendidikan Nasional.

Maryanto, A. (1994). Kurikulum Lintas Bidang Study. Jakarta: Grasindo.

Mulyasa, E. (2007). Kurikulum tingkat satuan pendidikan sebuah panduan praktis. Bandung: PT Remaja Rosdakarya.

Nasional, D. P. (2006). Panduan Pengembangan Pembelajaran IPS Terpadu. Jakarta: Puskur, Balitbang Depdiknas. 
Prekar, H. (2018). wawancara dengan Kepala Sesi Kurikulum Dinas Pendidikan Kota Padang, 28 September. padang.

Syair, S. (2018). wawancara mengenai pembelajaran IPS secara terpadu dapat dilaksanakan oleh guru tanggal 13 oktober 2018. Padang.

Trianto, M. P. (2012). Model pembelajaran terpadu: Konsep, strategi, dan implementasinya dalam Kurikulum Tingkat Satuan Pendidikan (KTSP). Kuala Lumpur: Kemetrian Pengajaran Malaysia.

Watni. (2018). Wawancara mengenai pembelajaran IPS secara terpadu dapat dilaksanakan oleh guru,tanggal 24 Oktober 2018. Padang.

Yarmina, Y. (2018). Wawancara mengenai kesulitan dalam pembelajaran IPS yang terpadu. Padang. 